International Review of Research in Open and Distributed Learning Volume 18, Number 7

November - 2017

\title{
The Impact of Whatsapp Use on Success in Education Process
}

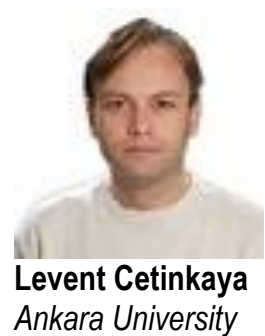

\begin{abstract}
The purpose of this study is to explore the effects of WhatsApp use for education and determine the opinions of students towards the process. The study was designed in mixed research model which combines both qualitative and quantitative data. In the quantitative aspect of the study, quasi-experimental design, with a pretest-posttest control group, was used and the data were analyzed by two factor variance analysis for mixed measurements. The analysis indicated that both learning environments have different effects on the success of students and that supporting the traditional environment by using WhatsApp is more effective for the increase of success. For the qualitative aspect of the study, content analysis techniques were employed to analyze the data which were collected by open-ended question forms. The analysis showed that students developed positive opinions towards the use of WhatsApp in their courses. They demanded the same practice in their other courses as well. They reported that learning could also take place unconsciously and the messages with images were more effective for their learning. However, a few students have expressed adverse opinions about the timing of some posts and the redundant posts within the group. Finally, it is suggested that use of WhatsApp in education process be encouraged as a supportive technology.
\end{abstract}

Keywords: WhatsApp, instant message, social network, mobile social learning, students' performance

\section{Introduction}

With their increasing time, scope, and frequency of use, internet technologies have started to shape the way people form and share content and their way of communication. Social networks, which are very popular among young people, are becoming prevalent due to their nature to meet the needs of individuals towards socialization. Their nature that focuses on individuals, started to shape users' process of interaction and has 
become one of the important elements of the daily life. The high number of people joining social networks, which are defined as programs that ease the interaction between individuals and groups, provide various opportunities for social feedback and support the formation of tangled social relations (Boyd, 2003), show how immense the people's need is for these networks. Within the framework of these needs, development of mobile versions of these programs that carry the social structure from real life to virtual environment and eliminate the time and space limitations, has become inevitable. This process, which started by commonly used web based social networks (Facebook, Twitter, etc.) in particular, began to be approached in different dimensions after the introduction of the messaging applications rooted in mobile phones and are specifically designed for mobile phones (WhatsApp, BBM, Line, etc.).

Though they differ structurally to some extent (Boyd \& Ellison, 2007; Taylor, Lewin, \& Strutton, 2011), it hasn't taken much time for the social networks, which have become a part of users' daily lives, to be used in education. Consequently, together with the individual and social effects of social networks, their usability and effects in education started to be examined by the researchers. The studies indicate that social networks have both positive and negative effects over different variables (communication, motivation, social interaction, academic success, etc.) depending on their purpose and form of use in education. It is seen that these tools, each of which has different features for learning aims, have potentials to provide cooperation, increase social interaction, interest and motivation, sense of belonging, academic success, student-student and student-teacher interaction, support learning anytime and anywhere, provide peer support, feedback, and allow for sharing of information in education. Apart from the studies underlining the positive aspects of using them in education, depending on their purpose and form of use, concerns towards privacy and security, losing attention, getting beyond the limits in personal relations, use of slang language, and negative effects on academic life arising from excessive use, have also been determined in the results of the studies.

The presence of positve and negative sides of social networks does not change the fact that these tools are rapidly becoming popular, gaining an important place in our lives, and starting to take their place in education. In recent years, instant messaging applications, which can be identified as mobile-based social networks, have started to become popular. Though there are a lot of instant messaging applications that can operate on mobile devices, it is seen that WhatsApp application is one of the most favored mobile based applications (see SimilarWeb, 2016; Statista, 2016). In their study, Church and de Oliveira (2013) emphasize this fact and state that WhatsApp has grown in popularity due to its benefits such as, being able to send real-time messages to an individual or groups of friends simultaneously, low-cost, and privacy.

However, in studies on the use of different instant messaging platforms in education, it is also determined that these applications have potential to increase learning (Smit, 2012), learners' being active in their studies (Cifuentes \& Lents, 2010), interaction between students on personal, school, and course related topics (Cifuentes \& Lents, 2010; Smit, 2012), create sense of belonging (Doering, Lewis, Veletsianos, and Nichols-Besel, 2008; Sweeny, 2010), eliminate social barriers (Doering, Lewis, Veletsianos, Nichols-Besel, 2008), and increase students' motivation (Plana et al., 2013). By the help of these benefits, which are also supported by the studies conducted on WhatsApp (Bouhnik \& Deshen, 2014; Church \& de Oliveira, 2013; Nguyen \& Fussell, 2016), it is noted that the application can be a useful tool within the scope of learning anytime and anywhere, and collaborative learning. In this case, as such in Facebook, Twitter, and other 
social networks, it won't take a long time for WhatsApp to influence the learning environments as well as the social life.

The potential of the social networks when designed in accordance with the needs of science and information, is alleged to cause revolutionary changes (Zaidieh, 2012), and their influence on the educational environment is increasing rapidly everyday, especially with the help of the internet supported mobile technologies. This potential, which enables cooperative synchronous and asynchronous communication together with their multimedia support, and cover the features of social networks on a large scale, should not be disregarded. Recently, instant messaging has become a top-priority and popular for children (Cetinkaya \& Sütçü, 2016; Harrison \& Gilmore, 2012; Lenhart, Purcell, Smith, and Zickuhr, 2010), the studies on the effects of new generation instant messaging applications upon interaction between people and learning-teaching processes are very limited. On the other hand, the presence of evidence that support the fact that these applications have a great effect on the social development of young people necessitates the determination of their impact on their academic development and expectations. Consequently, the purpose of this study is to explore the effects of WhatsApp use for education and determine the opinions of students towards the process.

In line with this purpose, answers to the following questions are sought:

1. Do students' success scores show a significant difference when WhatsApp is used as a support to the traditional environment?

2. What are the students' opinions on the educational use of WhatsApp application and the study process?

\section{Methodology}

In this section, there are explanations about the model of the research, study group, data collection, and analysis of the data.

\section{The Model of the Study}

Mixed method model, which combines both qualitative and quantitative approaches, was used in this study. By using mixed methods research, strong aspects of quantitative and qualitative methods can be utilised and its limitations can be minimised (Creswell, 2003; Creswell \& Plano Clark, 2007; Johnson \& Christensen, 2008; Tashakkori \& Teddlie, 2003). Particularly, complexity of social facts is eliminated by bringing different methods together then observing and discussing them, which hereby contributes to the better understanding of the fact (Creswell, 2003). In this study, explanatory mixed methods was employed, further described in Table 1. 
Table 1

Explanatory Mixed Method Design

\begin{tabular}{ccc}
\hline Quantitative & Qualitative \\
\hline $\begin{array}{c}\text { Quasi-experimental } \\
\text { study and its results }\end{array}$ & Follow-up & $\begin{array}{c}\text { Case study and data } \\
\text { and results }\end{array}$ \\
\hline
\end{tabular}

In explanatory mixed method design, the researcher first collects the quantitative data and then the qualitative data respectively. This means in explanatory mixed method design, quantitative data collection and its analysis have the priority. In addition, in order to correct the results from the quantitative data, the researcher uses qualitative data (Creswell, 2005). Within this framework, in order to determine the effects of the information sent via WhatsApp with regards to success, a pretest-posttest control group quasiexperimental design, which forms the quantitative aspect, was used. In quasi-experimental design, which is described as the best research design to explain cause-effect relationships, the treatment is performed after the pretest and finally, posttest is given to determine the effect on dependent variable (Fraenkel \& Wallen, 2006). The selection of experimental and control groups, and the research design of quasiexperimental design according to some pre-evaluations and criteria, are provided in Table 2.

Table 2

Quasi Experimental Design Research View

\begin{tabular}{llll}
\hline Group & Pre experimental & Experimental process & Post experimental \\
\hline Experimental & PreTest (AT) & WhatsApp Info Message & PostTest (AT) \\
Control & PreTest (AT) & Traditional & PostTest (AT) \\
& & Environment & \\
\hline
\end{tabular}


and traditional environment; Dependent variable: Success.

In the quantitative aspect of the research, the effects of the information packs that were sent to students as support to the traditional teaching via WhatsApp in the experimental group were compared. In the qualitative part of the research, the case study, which belongs to the qualitative research tradition, was utilised. Qualitative research is an approach that uses an inductive attitude in social studies and underlines descriptive data collection techniques in natural environments together with the views of the participants (Bogdan \& Biklen, 2006). As for case study, it tries to reveal present examples of application by using the question "how" (Yıldırım \& Şimşek, 2008). In this part of the research, students' opinions on the application process were taken.

\section{Study Group}

The participants of the study were secondary education $10^{\text {th }}$ grade students, aged between $15-16$. In the study, criterion sampling which is one of the purposive sampling methods was used. In the selection of the study group, the criteria that ensure the continuity of the experimental processes, the ease of accessibility to participants, the proximity of prior knowledge levels, and the provision of the necessary technological infrastructure, are taken into consideration. Accordingly, two (X and Y) out of three, 1oth grade literature 
classes taught by the same teacher were chosen. Before the research, pretest was given to the students of these two classes to determine the prior knowledge and control the normality and the homogenity of their distribution. After the pretest, homogenity (Levene's Test $\mathrm{F}=0.002, \mathrm{p}>.05$ ) and normality (KolmogorovSmirnov test, $\mathrm{p}>$.05) between the classes were observed. Before the experimental process, unrelated samples t-test was performed to see if there was a significant difference between the scores of the students in both groups, and as a result of the analyses, no significant difference was found in the arithmetic mean scores of the students $(\mathrm{t}(58)=0.361, \mathrm{p}>.05)$.

In line with these results, it was decided to evaluate the two classes under two different groups; experimental and control groups. In this way, no discrepancies could be made between students and applications, and the interaction between the individuals in the same class was avoided. In separation of the classes as experimental and control groups, their possession of smartphone, internet, and the usage of WhatsApp were taken into consideration. It was established that in class X, 2 out of 30 students did not have smartphones, and while three students had smartphones, they did not have WhatsApp installed on their phones. However, in class Y, all 30 students had smartphones, while two students did not have WhatsApp installed on their phones. From the prior knowledge of the students, it was inferred that, in terms of technical requirements, class $\mathrm{Y}$ was deemed more advantageous. As a result, class $\mathrm{X}$ was designated as the control group with class Y designated as the experimental group. Students in group Y were informed about the purpose of the research and were asked if they wanted to participate in the research. Students who did not have the WhatsApp on their phones but wanted to participate in the study, were provided seven additional days to resolve it. At the end of this period, all the students, including the ones who had not used WhatsApp before, met the prerequirements.

As detailed in Table 3, the study, which was conducted with 15 female and 15 male experimental group students, and 16 female and 14 male control group students, for a total of 60 student participants, ended with the complete participation of all students in the quantitiative research stage. As for the qualitative research stage, 30 students from the experimental group after the posttest participated.

Table 3

Gender Distribution of the Study Group

\begin{tabular}{lcccccc}
\hline \multirow{2}{*}{ Study groups } & \multicolumn{3}{c}{ Female } & \multicolumn{2}{c}{ Male } & \multicolumn{2}{c}{ Total } \\
\cline { 2 - 7 } & $f$ & $\%$ & $f$ & $\%$ & $f$ & $\%$ \\
\hline Control Group & 16 & 53.3 & 14 & 46,7 & $\mathbf{3 0}$ & $\mathbf{5 0 , 0}$ \\
\hline Experimental Group & 15 & 50,0 & 15 & 50.0 & $\mathbf{3 0}$ & $\mathbf{5 0 , 0}$ \\
\hline Total & $\mathbf{3 1}$ & $\mathbf{5 1 , 7}$ & $\mathbf{2 9}$ & $\mathbf{4 8 , 3}$ & $\mathbf{6 0}$ & $\mathbf{1 0 0 , 0}$ \\
\hline
\end{tabular}

\section{Implementation Phase}

The face-to-face education of all the students in the study group was conducted by the same teacher. The researcher only sent information messages to the students in the experimental group without any interferences. 
Creation of information messages. Information messages sent to the students to determine the contribution of WhatsApp use to education, comprised of the topics that 1oth grade students had not covered before. Information texts to be given with 30 information messages, which were created by four teachers who had at least 10 years of teaching experience, were formed and supportive images were chosen to be given with 15 of the messages. Upon the revision of the information messages by two academicians from the department of literature education and one academician from the department of educational technology, they were finalized. Information texts, which had the number of words between 19-81, had the core information to cover the replies to questions during the pretest and posttest. Images were chosen by the same teachers and academicians who contributed to the creation of the texts.

Sending the information messages. Fifteen information texts which were chosen by expert views and 15 information messages consisting of information text and supportive images, were sent concurrently when the related topics were taught in the curriculum. Information messages were sent by the researcher, once per day and at random times, concurrently with the related course content during the day (08:30-21:00).

As can be seen in the WhatsApp screenshot in Figure 1, information messages were sent simultaneously with the supportive images and the text messages during the application process.

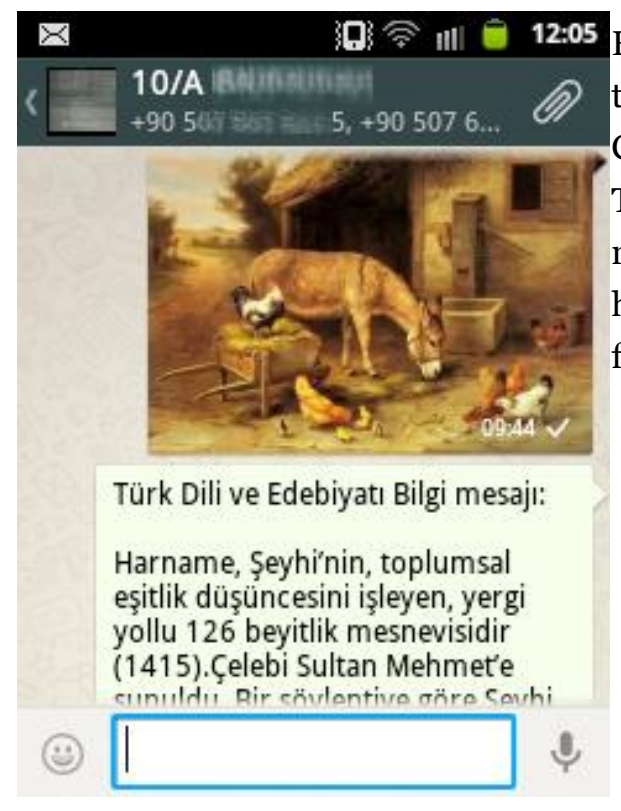

Harname is Seyhi's satirical masnavi of 126 couplets on the idea of social equality (1415). It was presented to Chalabi Sultan Mehmet. It is rumored that Seyhi cured The Sultan during his campaign to Iran and was rewarded with the village of Tokuzlar as timar. While he was on the way to the village, he was beaten by the former holders of timar and thus he wrote Harname.

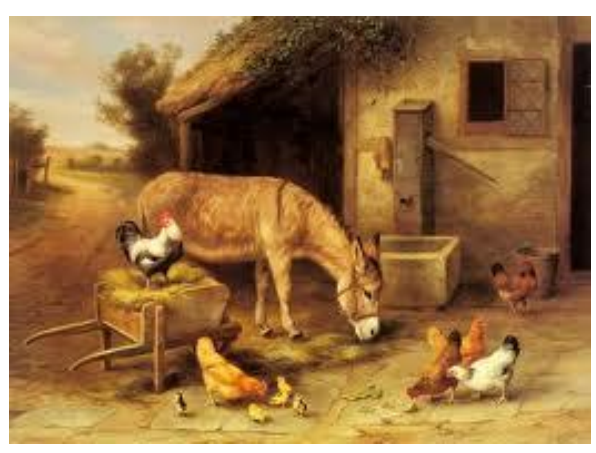

Figure 1. Information message sample.

\section{Data Collection}

The quantitative data of the study were collected by open-ended questions having short answers both before and after the application. Teachers and academicians who prepared the information texts decided on the questions. During this phase, the curriculum for the face-to-face education was followed and questions to test different knowledge levels were prepared. The questions were clear and comprehensible, the answers 
expected for the questions were clear and required single answers which were covered in the information messages sent via WhatsApp. Hence, the reliability of the evaluation phase of the exam was ensured. For example, after sending the information text:

NEDIM, an ottoman poet, gained his fame during The Tulip Period of The Ottoman Empire between the years 1718-1730. He is recognised as a representative of this period's spirit with his works and life. He is seen as a notable figure of this period which is salient with its poem and esthetics, art and fun trends. The poet, who is famous for his lyrics and odes, introduced the genre of song to the Ottoman Poetry. However, the first song poet is Nail-i Kadim.

The students were asked "What is the type of poetry brought to Ottoman Poetry by Nedim?" and their answer "song" was accepted as the correct answer. A pretest was given two weeks before, and the posttest two weeks after, the information messages were sent, which lasted 30 days. Pretest and posttest were given uder the supervision of two teachers and the researcher in classroom environment.

Qualitative data were collected by using open-ended question form one week after the posttest was given to 30 students in experimental group. The students were informed about the open-ended question form and were asked to answer the research question; "Write your ideas about the process of sending information messages via WhatsApp application and your suggestions, if any." The question to determine their opinions was given in written form to the students in the classroom environment under the supervision of the researcher to enable them to give detailed answers.

\section{Analysis of the Data}

The achievement test with short answers were given simultaneously to both experimental and control group at the begining and the end of the study. In achievement test, one point was given to each correct answer and zero points to each wrong or blank answer. The questions in achievement tests (pretest and posttest) were given in eight week intervals and evaluated. Since there was homogenity in classes, the distribution met the assumption of normality, and the study was conducted with two groups, t-test was utilised for the analysis of the data. To test the effectiveness of environments $2 \mathrm{X} 2$ split plot design was used and two factor variance analysis for mixed measures was used to analyze this research question. The significance of the difference between mean scores was calculated at the level of $p=.05$ and SPSS was used in the analysis of data.

For the analysis of the written data obtained by open-ended question form which constituted the qualitative aspect of the research, categorical analysis which is one of the content analysis types and frequency analysis were utilised. In categorical analysis; (1) coding of the data, (2) forming categories, (3) organisation of categories, and (4) description of findings and interpretation stages were followed (Corbin \& Strauss, 2007). Frequency analysis revealed the quantitative frequency of the data, thus determining the density and the importance of a particular factor (Ryan \& Bernard 2000; Tavşancıl \& Aslan, 2001). Hence, the qualitative data were digitalised and their reliability increased, biasness decreased, and comparison of the data was enabled (Yıldırım \& Şimşek, 2008). 


\section{Findings and Interpretations}

The findings are given below in the order of research methodologies and sub-problems.

\section{Findings for Quantitative Data}

To test the effectiveness of the learning environments, 2X2 split plot design was used. In the design, the first factor meant two separate experimental environments (traditional environment-WhatsApp as supportive technology to the traditional environment), second factor meant measurements (pretestposttest) before and after the experiment (Büyüköztürk, 2007). Two factor variance analysis for mixed measurements was done to analyse the research question. Students' mean scores of pretest and posttest, depending on their learning environments and standard deviation value, are given in Table 4.

Table 4

Learning Environments Mean and Standard Deviation Values

\begin{tabular}{lccccc}
\hline \multicolumn{1}{c}{ Group } & & \multicolumn{2}{c}{ Pretest } & \multicolumn{2}{c}{ Posttest } \\
& $\mathbf{N}$ & $\overline{\mathbf{x}}$ & $\mathbf{S}$ & $\overline{\mathbf{x}}$ & $\mathbf{S}$ \\
\hline Control & 30 & 3.83 & 2.44 & 11.57 & 3.41 \\
Experimental & 30 & 3.60 & 2.57 & 19.63 & 4.41 \\
\hline
\end{tabular}

While the mean success scores of the students in traditional environment before the experiment is 3.83 , this value increased to 11.57 after the experiment. Mean success scores of the students in the environment which WhatsApp is used as a supplementary technology to traditional environment are 3.60 and 19.63 respectively. Accordingly, it can be declared that there is an increase in the success of the students learning in both the traditional environment and in the environment which the WhatsApp is used as a supplemantary technology. The results of the two factor ANOVA analysis which was made to analyse if the success scores of the students in two separate environments showed a significant difference are given in Table 5 .

Table 5

ANOVA Results of Learning Environments Relating to Pretest-Posttest Scores

\begin{tabular}{lcrcrc}
\hline Source of variance & $\begin{array}{c}\text { Sum of } \\
\text { squares }\end{array}$ & sd & Mean squares & F & p \\
\hline Between subjects & 1393.491 & 59 & & & \\
$\quad$ Group & 460.208 & 1 & 460.208 & 28.600 & .000 \\
(Individual/Group) & 933.283 & 58 & 16.091 & & \\
$\quad$ Hata & 5085.500 & 60 & & & \\
Within subjects & 4236.408 & 1 & 4236.408 & 739.168 & .000 \\
Measurement (Pretest- & $\mathbf{5 1 6 . 6 7 5}$ & $\mathbf{1}$ & $\mathbf{5 1 6 . 6 7 5}$ & $\mathbf{9 0 . 1 4}$ & $\mathbf{. 0 0 0}$ \\
Posttest) & 332.417 & 58 & 5.731 & & \\
Group*Measurement & $\mathbf{6 4 7 8 . 9 9 1}$ & 119 & & & \\
Error & & & & & \\
Total & &
\end{tabular}


According to the findings, the success of the students in two different learning environments show a significant difference before and after the experiment, in other words, the common effect of being in a different environment and the factors of repeated measures on success is significant $\left(F_{(1-58)}=90.14, p<.001\right)$. This finding shows that both learning environments have different effects on increasing the success of students. The environment in which WhatsApp was used as a supportive technology to traditional environment has been more effective in the increase of success.

\section{Findings for Qualitative Data}

Students' views in experimental group about the process of sending information messages via WhatsApp, were collected by an open-ended question form. The ritten data were analysed using categorical analysis, which is one of the content analysis types, and frequency analysis, which is displayed in Table 6 with the results of students' opinions ( $\mathrm{S}+$ student code):

Table 6

Students' Opinions About Sending Information Messages via WhatsApp

\begin{tabular}{lll}
\hline Positive & $\boldsymbol{f}$ & \% \\
\hline $\begin{array}{l}\text { The will for similar applications for the other } \\
\text { course }\end{array}$ & 25 & 83.3 \\
\hline Realization of learning (conscious or unwittingly) & 18 & 60.0 \\
\hline Increase of the interest using posts with images & 14 & 46.7 \\
\hline Negative & & \\
\hline Timing of the posts & 7 & 23.3 \\
\hline Redundant messages within the group & 6 & 20.0 \\
\hline
\end{tabular}

It was determined that majority of the students believe that using the application for all courses would be useful. As stated by S14 "The application would be fine in biology lesson" and S22 "if used in other lessons they could be more enjoyable... I could learn easily," students emphasize their will to see the application in their other courses. One of the important factors that is effective in their will is realization of learning. At this point it is remarkable that, besides learning after a conscious process, there are students who had expressed that learning can also take place unconsciously: S13 explains that "I didn't know that the last exam would be held. But I could answer most of the questions without revising at all," S21 shares that "I realised that I learnt unconsciously during the exam," and S17 states that "even reading the messages I got was enough, I didn't do any revision at all but I could remember most of the messages." Such statements all underline that learning can take place unconsciously. This shows that without any special effort, even by only following the posts, it can contribute to learning positively. The other positive opinion is about the images that are sent within the information messages. S11 shares that "images sent with the texts helped me remember them easily," and S16 reveals that "I wish they were all with images." As stated above, information messages sent with related images are received more favorably by the students.

The most important factor that was characterised negatively by the students towards the process of sending information messages by means of the WhatsApp application is the timing of information messages. As can be seen in S10's statements, "we received some messages just in the middle of the lesson and this caused us to lose our interest in the lesson." Though these messages were limited in number, some students expressed 
negative opinion on the timing of the messages; as stated by S9, there is a need to "be careful with the timing of the messages." Another problem is sending messages within the group. Though the purpose in forming the group is known by the students, some messages which were out of purpose were sent as stated by K29: "some friends sent unnecessary messages in the group, so we warned them" and they were resolved within the group and without researcher's intervention.

\section{Results and Conclusion}

In this research, which was conducted with 1oth grade secondary education students, the determination of the impact of WhatsApp use on success in education process, which is one of the instant messaging application, and the opinions of the students towards the process was aimed. Depending on the purpose of the research, qualitative and quatitative data collection methods were employed and was designed in mixed research model which integrates the results of the study. After the analysis, the results are discussed within the literature and the recommendations are given under headings.

\section{Results}

Results for quantitative data. To determine the contribution of WhatsApp to education as a supportive technology, a pretest-posttest control group, quasi-experimental design was used. The data related to the effectiveness of information packages on success, sent via WhatsApp to the students in the experimental group as a support to traditional environment, were analysed by using two factor variance analysis for mixed measurements. The results indicated that there is an increase in the success of the students, both in the traditional environment and in the environment in which WhatsApp was used as a supportive technology. According to the results of the two factor ANOVA analysis, which was made to test whether these changes showed a significant difference, it was determined that the success of the students who studied in two separate environments showed a significant difference. This finding indicates that both learning environments have different impacts on the increase of students' success, and supporting the traditional environment with WhatsApp, has been more effective on students' success.

The researches made on social networks and the integration of instant messaging have shown that the features such as: encouraging collaborative learning which contributes to learning process, active participation, learning anytime and anywhere, and informal communication, are common in all platforms (Arteaga Sánchez, Cortijo, \& Javed, 2014). Although there aren't any experimental studies met on the use of WhatsApp, which is one of the instant messaging applications, towards its impact on academic success in educational environments, there are findings that show its support to collaboration and sharing of the content, provide an unstructured learning environment (Arteaga Sánchez et al., 2014; Bouhnik \& Deshen, 2014; Church \& De Oliveira, 2013; Nguyen \& Fussell, 2016; Rambe \& Bere, 2013; Rambe \& Chipunza, 2013). The results of the study show that the application has potential to increase the success.

Results for qualitative data. After the implementation of open-ended question form to students in experimental group, content analysis was done and students' opinions about the process were categorised and correlated accordingly. Majority of the students expressed that the application has a positive effect on motivation and its use in other courses would be useful. In their study, which they conducted through 
WhatsApp on language education, Plana et al., (2013) have also found that the instant messaging application WhatsApp increase students' motivation and willingness to study in immersion programmes. Another important factor that influence students' willingness for similar implementation in their other courses, is the realization of learning. In his study, Smit (2012) stated that instant messaging applications have potential to increase learning. In the study, students' statements that learning can also take place unconsciously besides a conscious process, are remarkable. In his study on social networks, Leonardi (2014) also implied that learning can take place by observing others' studies and communications. Another factor towards the implementation process, which is responded positively to by students, is the images used to support information texts. Students stated that these images, which were sent with some information texts and were related to the texts, had a positive contribution to their learning. However, the fact that the learners learn better in environments when words and images are used together rather than single words (Mayer, 2001; 2003), is supported with theoretical basis (Dual coding, limited capacity, multimedia learning, etc.), and has been tested in many researches.

It is observed that the most important factor that students refer as negative in relation to sending of information messages via WhatsApp application is the timing of the messages. Though in limited numbers, some statements of the students, particularly about the untimely messages that may cause distraction, shows that special care must be taken in the timing of the messages. Another negativity in the process of implementation is the messages within the group. Although the students were informed about the purpose of the group, there were unnecessary and disturbing messages; however, this was resolved within the group without the interference of the researcher. This shows that there is self-control within the group and students can overcome such situations between each other. In their research on the use of WhatsApp, Bouhnik and Deshen (2014) state similar problems, but unlike this study, the students' solution was silencing the group. At this point, in research on social networks and the use of mobile devices, it is mentioned that students' untimely and unnecessary messages may cause distraction among students and their study process could get negatively effected (Kusnekoff, Munz, \& Titsworth, 2015; McCoy, 2013, 2016).

\section{Conclusion}

As in face-to-face communication, disagreements are inevitable in virtual environments when there is a human factor. However, minimisation of the problems is possible by managing the process properly and making out the possible problems. However, social networks are applications that started to become a part of education in the natural flow of daily lives. In the studies on these applications, generally, minimisation of the problems and use of their potential to support education processes are emphasized. Also, in this research, it was mentioned that they provide unstructured learning environment and can be used as effective tools in education (Cain \& Policastri, 2011; Lampe, Wohn, Vitak, Ellison, and Wash 2011; Madge, Meek, Wellens, and Hooley, 2009; Towner \& Munoz, 2011; Arteaga Sánchez et al., 2014; Norman, Nordin, Din, Ally, and Dogan, 2015). Yet, it is early to know what impact the WhatsApp application, which has an important place in the daily lives of youg people and has the qualities to be recognised as social network, will have on education. As a result of this study, it is determined that the application has a positive impact on success and its use is welcomed substantially. It should not be disregarded that WhatsApp technology has the potential of a natural educational technology and the qualities to contribute to education as a 
supportive technology. Within this framework, there are a lot of theoretical and practical questions regarding the use of application in education to be answered, some of which can be listed below:

- The impact of WhatsApp on the process of education in other courses should also be researched.

- Necessary precautions should be taken to minimize the drawbacks expressed by the students.

- With reference to the students' opinion that the images increased their interest in the topic, studies which include other multimedia elements (audio, video, animation, etc.) should be conducted and their impacts be compared.

- In line with the results based on the qualitative data attained from the opinions of students, experimental studies should be conducted to verify the qualitative data.

- Educators' opinions on the use of WhatsApp and similar applications in education should be asked and they should be involved in the process.

- Similar studies should be repeated with other grades, as well.

\section{References}

Arteaga Sánchez, R., Cortijo, V., \& Javed, U. (2014). Students' perceptions of Facebook for academic purposes. Computers \& Education, 70, 138-149. doi: http://dx.doi.org/10.1016/j.compedu.2013.08.012

Bogdan, R. C., \& Biklen, S. K. (2006). Qualitative research for education to theory and methods (5th ed.). Boston: Allyn \& Bacon.

Bouhnik, D., \& Deshen, M. (2014). WhatsApp goes to school: Mobile instant messaging between teachers and students. Journal of Information Technology Education: Research, 13, 217-231. Retrieved from http://www.jite.org/documents/Vol13/JITEv13ResearchP217-231Bouhniko6o1.pdf

Boyd, S. (2003). Are you ready for social software? [Blog post]. Retrieved from http://www.stoweboyd.com/post/2325281845/are-you-ready-for-social-software

Boyd, D. M., \& Ellison, N. B. (2007). Social network sites: Definition, history, and scholarship. Journal of Computer-Mediated Communication, 13(1), 210-230. doi: http://dx.doi.org/10.1111/j.1083$\underline{6101.2007 .00393 . x}$

Büyüköztürk, Ş. (2007). Deneysel desenler: Öntest-sontest kontrol grubu desen ve veri analizi (2. baskı) [Experimental designs: Pretest-posttest control group design and data analysis (2nd. ed.)] Ankara: PegemA Yayıncılık. 
Cain, J., \& Policastri, A. (2011). Using Facebook as an informal learning environment. American Journal of Pharmaceutical Education, 75(10): 207. doi: http://dx.doi.org/10.5688/ajpe7510207

Cetinkaya, L., \& Sütçü, S. S., (2016). Parents' restrictions on their children's use of information technologies and their reasons. Turkish Online Journal of Qualitative Inquiry, 7(1), 18-36. doi: http://dx.doi.org/10.17569/tojqi.58102

Church, K., \& de Oliveira, R. (2013). What's up with WhatsApp? Comparing mobile instant messaging behaviors with traditional SMS. Proceedings of the 15th International Conference on Humancomputer Interaction with Mobile Devices and Services (pp. 352-361). New York, USA: ACM. doi: http://dx.doi.org/10.1145/2493190.2493225

Cifuentes, O. E., \& Lents, N. H. (2011). Increasing student-teacher interactions at an urban commuter campus through instant messaging and online office hours. Electronic Journal of Science Education, 14(1), 1-13. Retrieved from http://ejse.southwestern.edu/article/view/7314

Corbin, J. M., \& Strauss, A. C. (2007). Basics of qualitative research: Techniques and procedures for developing grounded theory. Thousand Oaks, CA: Sage Publication.

Creswell, J. W. (2003). Research design: Qualitative, quantitative, and mixed methods approaches. (2nd ed.). Thousand Oaks, CA: Sage.

Creswell, J. W. (2005). Educational research: planning, conducting, and evaluating quantitative and qualitative research (2nd ed.). New Jersey: Merrill Prentice Hall.

Creswell, J. W., \& Plano Clark, V. L. (2007). Designing and conducting mixed methods research. Thousand Oaks, CA: Sage.

Creswell, J. W., Plano Clark, V. L., Gutmann, M., \& Hanson, W. (2003). Advanced mixed- methods research designs. In A. Tashakkori \& C. Teddlie (Eds.), Handbook of mixed methods in social and behavioral research (pp. 209-24O). Thousand Oaks, CA: Sage.

Doering, A., Lewis, C., Veletsianos, G., \& Nichols-Besel, K. (2008). Preservice teachers' perceptions of instant messaging in two educational contexts. Journal of Computing in Teacher Education, 25(1), 5-12. Retrieved from http://files.eric.ed.gov/fulltext/EJ834086.pdf

Fraenkel, J. R., \& Wallen, N. E. (2006). How to design and evaluate research in education. Boston: McGraw-Hill.

Harrison, M. A., \& Gilmore, A. L. (2012). U txt when? College students' social contexts of text messaging. The Social Science Journal, 49, 513-518. doi: http://dx.doi.org/10.1016/j.soscij.2012.05.003

Johnson, B., \& Christensen, L. (2008). Educational research: Quantitative, qualitative and mixed approaches (3rd ed.). California: SAGE. 
Kusnekoff, J., Munz, S., \& Titsworth, S. (2015). Mobile phones in the classroom: Examining the effects of texting, Twitter, and message content on student learning. Communication Education, 64(3), 344-365. doi: http://dx.doi.org/10.1080/03634523.2015.1038727

Lampe, C., Wohn, D. Y., Vitak, J., Ellison, N. B., \& Wash, R. (2011). Student use of Facebook for organizing collaborative classroom activities. Computer-Supported Collaborative Learning, 6(3), 329-347. doi: http://dx.doi.org/10.1007/s11412-011-9115-y

Lenhart, A., Purcell, K., Smith, A., \& Zickuhr, K. (2010). Social media and young adults. Washington D.C.: Pew Internet \& American Life.

Leonardi, P. M. (2014). Social media, knowledge sharing, and innovation: Toward a theory of communication visibility. Information Systems Research, 25, 796-816. doi: http://dx.doi.org/10.1287/isre.2014.0536

Madge, C., Meek, J., Wellens, J., \& Hooley, T. (2009). Facebook, social integration and informal learning at university: 'It is more for socialising and talking to friends about work than for actually doing work'. Learning, Media and Technology, 34(2), 141-155. doi: http://dx.doi.org/10.1080/17439880902923606

Mayer, R. E. (2001). Multimedia learning. Cambridge: Cambridge University Press.

Mayer, R. E. (2003). The promise of multimedia learning: using the same instructional design methods across different media. Learning and Instruction. 13(2), 125-139. doi: http://dx.doi.org/10.1016/So959-4752(02)00016-6

McCoy, B. R. (2013). Digital distractions in the classroom: student classroom use of digital devices for non-class related purposes. Journal of Media Education, 4(4), 5-14. Retrieved from http://digitalcommons.unl.edu/journalismfacpub/

McCoy, B. R. (2016). Digital distractions in the classroom phase II: Student classroom use of digital devices for non-class related purposes. Journal of Media Education, 7(1), 5-32. Retrieved from http://digitalcommons.unl.edu/journalismfacpub/

Nguyen, D. T., \& Fussell, S. R. (2016). Effects of conversational involvement cues on understanding and emotions in instant messaging conversations. Journal of Language \& Social Psychology, 35(1), 28-55. doi: http://dx.doi.org/10.1177/0261927X15571538

Norman, H., Nordin, N., Din, R., Ally, M., \& Dogan, H. (2015). Exploring the roles of social participation in mobile social media learning: a social network analysis, International Review of Research in Open and Distributed Learning, 16(4), 205-224. doi: http://dx.doi.org/10.19173/irrodl.v16i4.2124

Plana, M. G- C., Escofet, M. I. G., Figueras, I. T., Gimeno, A., Appel, C., \& Hopkins, J. (2013, July). Improving learners' reading skills through instant short messages: A sample study using 
WhatsApp. 4th World-CALL Conference, Glasgow. Retrieved from

https://www.researchgate.net/publication/255718202 Improving learners' reading skills thr ough instant short messages a sample study using WhatsApp

Rambe, P., \& Bere, A. (2013). Using mobile instant messaging to leverage learner participation and transform pedagogy at a South African University of Technology. British Journal of Educational Technology, 44(4), 544-561. doi: http://dx.doi.org/10.1111/bjet.12057

Rambe, P., \& Chipunza, C. (2013). Using mobile devices to leverage student access to collaborativelygenerated re-sources: A case of WhatsApp instant messaging at a South African University. International Conference on Advanced Information and Communication Technology for Education (ICAICTE 2013). doi: http://dx.doi.org/10.2991/icaicte.2013.66

Ryan, G., \& Bernard, H. R. (2000). Data management and analysis methods. In N. Denzin \& Y. Lincoln (Eds.), Handbook of qualitative research (pp. 769-802). Thousand Oaks, CA: Sage.

SimilarWeb. (2016). Mobile app ranking. Retrieved from https://www.similarweb.com/

Smit, I. (2012). WhatsApp with BlackBerry; Can messengers (BBM) be MXit? In Proceedings of the 14th annual conference on world wide web applications. Cape Town, South Africa: Cape Peninsula University of Technology. Retrieved from http://hdl.handle.net/10394/13628

Statista. (2016). Statistics and market data on mobile internet \& apps. Retrieved from http://www.statista.com/

Sweeny, S. M. (2010). Writing for the instant messaging and text messaging generation: Using new literacies to support writing instruction. Journal of Adolescent \& Adult Literacy, 54(2), 121-130. doi: http://dx.doi.org/10.1598/JAAL.54.2.4

Tashakkori, A., \& Teddlie, C. B. (2003). Handbook of mixed methods in social and behavioral research. Thousand Oaks, CA: Sage.

Tavşancıl, E., \& Aslan. E. A. (2001). İçerik analizi ve uygulama örnekleri [Content analysis and example applications for oral, written, and other documents]. Ankara: Epsilon Yayınları.

Taylor, D. G., Lewin, E. J., \& Strutton, D. (2011). Friends, fans, and followers: Do ads work on social networks? How gender and age shape receptivity. Journal of Advertising Research, 51(1), 258275. doi: http://dx.doi.org/10.2501/JAR-51-1-258-275

Towner, T., \& Munoz, C. L. (2011). Facebook and education: A classroom connection? In C. Wankel (Ed.) Educating educators with social media: Cutting-edge technologies in higher education, (Vol. 1, pp. 33-57). Bingley, U, K.: Emerald. doi: http://dx.doi.org/10.1108/S20449968(2011)0000001005 
Yıldırım, A., \& Şimşek, H. (2008). Sosyal bilimlerde nitel araştırma yöntemleri (6.Baskı) [Qualitative research methods in social sciences (6nd ed.)]. Ankara: Seçkin Yayıncılık.

Zaidieh, A. J. Y (2012). The use of social networking in education: challenges and opportunities. World of Computer Science and Information Technology Journal (WCSIT), 2(1), 18-21. Retrieved from https://pdfs.semanticscholar.org/76e2/1doc5cc14238463aogeec33d5do6573a32d2.pdf

\section{Athabasca} University

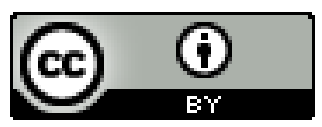

